\title{
POR UMA MILITÂNCIA ATIVA DA PALAVRA: ANTOLOGIAS, MOSTRAS, ENCONTROS E CRÍTICA SOBRE LITERATURA NEGRA, ANOS 1980
}

\author{
For the activism of the words: anthologies, \\ exhibitions, meetings and critics about the African- \\ Brazilian literature in the 1980s
}

Mário Augusto Medeiros da Silva*

\begin{abstract}
RESUMO
O interesse do artigo é discutir eventos, obras e debates na conjuntura da década de 1980, em São Paulo, em que intelectuais negros e não negros, nacionais e estrangeiros, trataram da ideia de Literatura Negra e a história política e cultural negra no Brasil e no exterior. Desta maneira, abordam-se a produção de antologias e obras críticas sobre a Literatura Negra Brasileira (como Reflexões sobre a literatura afro-brasileira e Criação Crioula, $\mathrm{Nu}$ Elefante Branco) e os encontros promovidos por intelectuais negros ou pelo poder público paulistano e associações privadas (o I Perfil da Literatura Negra - Mostra Internacional de São Paulo e os debates sobre literatura negra na III Bienal Nestlé de Literatura).
\end{abstract}

Palavras-Chave: Intelectuais Negros, Literatura Negra, Pensamento Social.

* Sociólogo, professor do Instituto de Filosofia e Ciências Humanas da Universidade Estadual de Campinas (IFCH-Unicamp). Este artigo foi elaborado a partir de minha tese de doutoramento, defendida em 2011 e apoiada pela Fundação de Amparo à Pesquisa do Estado de São Paulo [FAPESP]. A tese foi publicada homonimamente como A descoberta do insólito: literatura negra e literatura periférica no Brasil (1960-2000), Rio de Janeiro: Aeroplano, 2013. Agradeço a Petrônio Domingues e Flávio Gomes pelo convite à publicação do artigo. Contato: mariomed@unicamp.br 


\begin{abstract}
The interest of the article is to discuss events, works and debates in the 1980s the situation in São Paulo, in intellectual blacks and non-blacks, national and foreigners, treated the idea of Black Literature and the political and cultural history and black in Brazil abroad. In this way, approach to producing anthologies and critical works on the Black Brazilian Literature (Reflexões sobre a literatura afro-brasileira and Criação Crioula, $\mathrm{Nu}$ Elefante Branco) and meetings hosted by black intellectuals or the São Paulo government and private associations (the First Profile of Black Literature - International Exhibition of São Paulo and the debates about black literature on Third Biennial Nestlé of Literature).
\end{abstract}

Keywords: Black Intellectuals, Black Literature, Social Thinking.

\title{
Introdução
}

Para o estudo do associativismo político e cultural negro desde o final dos anos 1970, eventos ocorridos na década de $1980^{1}$ podem figurar como momentos importantes de reconfiguração de ideias, bem como de atuação no espaço público de um conjunto de intelectuais e ativistas negros, críticos de literatura defensores de uma estética e ética criativa que atende pelo nome de Literatura Negra ou Literatura afrobrasileira. Também se trataram de circunstâncias importantes para tentar estabelecer trocas de conhecimento sobre as realidades brasileira e africana, além de chamar à atenção o poder público sobre a história literária e social negra brasileira, cobrandolhe um posicionamento.

Intenta-se aqui discutir alguns desses encontros e eventos ocorridos em São Paulo, utilizando-se como fontes notícias de jornais, publicações de escritores e entrevistas com alguns dos participantes.

1 Algo que também sugerido nos trabalhos de: ALBERTI, Verena e PEREIRA, Amílcar (orgs.). Histórias do movimento negro no Brasil: depoimentos ao CPDOC, Rio de Janeiro: Pallas /CPDOC-FGV, 2007; PEREIRA, Amílcar Araújo. O mundo negro: relações raciais e a constituição do movimento negro contemporâneo no Brasil, Rio de Janeiro: Pallas, 2013. 
A capital paulista se impõe como local privilegiado por ter ocorrido ali, encontros de escritores negros brasileiros ao longo dos anos 1980. Auto-organizados (como aqueles que geraram os livros Reflexões ou Criação Crioula); ou ainda, estimulados externamente, como o Perfil de Literatura Negra - Mostra Internacional de São Paulo, em 1985 e, em 1986, a III Bienal Nestlé de Literatura. Além disso, é o espaço base do coletivo de escritores e intelectuais criadores da série Cadernos Negros, que edita, desde 1978, anualmente contos e poemas de autores negros, constituindo-se numa publicação distintiva e defensora de um projeto de literatura negra brasileira. Ademais, escritores que participavam centralmente ou orbitavam os Cadernos Negros [que tem, a partir de 1982, o grupo Quilombhoje como responsável por sua fatura] têm um papel que merece discussão: participando ou criticando, refletindo posteriormente sobre aqueles fatos.

Como ponto de partida, deve-se ter em mente que há uma história das condições sociais de existência do associativismo político e cultural negro paulistano que levam à possibilidade de congregação de um grupo de escritores negros em 1978. Isso se deve a uma trajetória que passa, para se restringir ao século XX após a Abolição, por jornais que compõem a história da Imprensa Negra Paulista ${ }^{2}$, bem como associações como a Frente Negra Brasileira [1931-1937] ${ }^{3}$ ou à Associação Cultural do Negro [1954-1976] ${ }^{4}$. É possível identificar a

2 Ver: BASTIDE, Roger. Estudos Afro-Brasileiros, São Paulo: Perspectiva, 1973; FERRARA, Miriam N. A imprensa negra paulista (1915-1963), São Paulo: FFLCH/USP, 1986; PINTO, Ana Flávia M. Imprensa negra no Brasil do século XIX, São Paulo: Selo Negro, 2010.

3 Cf. BICUDO, Virgínia Leone. Atitudes raciais de pretos e brancos em São Paulo, São Paulo: Sociologia e Política, 2010[ tese de 1945]; FERNANDES, Florestan. A integração do negro na sociedade de classes: no limiar de uma nova era, São Paulo: Ática, vol. 2, 3a.ed.,1978[1965]; PINTO, Regina Pahim. O movimento negro em São Paulo. Tese[Doutorado]. São Paulo: FFLCH/USP, 1993; ANDREWS, George R. Brancos e negros em São Paulo (18881988), Bauru: Edusc, 1998; DOMINGUES, Petrônio. A insurgência de ébano: a história da Frente Negra Brasileira (1931-1937). Tese [Doutorado]. São Paulo: FFLCH/USP, 2005.

4 Esta associação é mencionada por Florestan Fernandes (Op. Cit. 1978[1965]), Clóvis Moura (Organizações Negras In: BRANT, Vinícius C., SINGER, Paulo (orgs.) São Paulo: o povo em movimento, São Paulo: Cebrap/Vozes, 1980), Miriam Ferrara (Op. Cit. 1986), sendo que esses autores discutem rapidamente aspectos da organização e/ou utilizam os depoimentos de seus membros e jornais como fontes. Mereceu ainda menção em estudo de George Reid Andrews ( $O p$. Cit. 1998), uma apresentação em congresso, por Petrônio Domingues ( Associação Cultural do Negro (1954-1976): um esboço histórico, Comunicação apresentada no XXIV Simpósio Nacional de História, São Leopoldo, UNISINOS, 2007.), um capítulo de minha tese e livro (Op. Cit. 2011, 
participação de ativistas e intelectuais negros especialmente dessas duas últimas associações, como José Benedito Correia Leite (19001989) e Oswaldo de Camargo (1936-), em colaboração eventual ou ativa com os novos escritores e intelectuais negros emergidos à cena pública dos anos 1970, especialmente após 1978.

Os intelectuais negros mais velhos e sua experiência em associações mais antigas funcionam como elo, estabelecendo a conexão com uma memória coletiva negra do passado, permeada pelas lutas sociais e reivindicações daquele grupo. Da mesma forma, explicita-se, nesses contatos, que a literatura negra possui uma história e esforços de autodefinição, que passam pela existência de autores e obras, debate e experiências ${ }^{5}$, pouco conhecidos daqueles jovens nascidos nos anos 1950. Os debates e esforços da década de 1980 podem ser entendidos, desta maneira, como uma continuidade de uma trajetória perene de ativismo político e cultural, além de luta social por direitos do grupo negro literário em São Paulo.

2013) e um artigo em meu (SILVA, Mário A. M. da. Fazer história, fazer sentido: Associação Cultural do Negro (1954-1964). Lua Nova, São Paulo: CEDEC, n.85, pp. 227-273, 2012). Algumas vezes é referida equivocadamente, como em Regina Pahim Pinto (Op. Cit. 1993) e em SILVA, Joana Maria F. da. Centro de Cultura e Arte Negra: Trajetória e Consciência Étnica, Dissertação [Mestrado em Sociologia] PUC-SP, 1994.

${ }^{5}$ Ver: CUTI \& LEITE, José C. ...E disse o velho militante José Correia Leite, São Paulo: Secretaria Municipal de Cultura, 1992. Correia Leite fez o prefácio do terceiro volume da série Cadernos Negros, em 1980. Além disso, ver: "Na verdade, o que acontece hoje - eu acredito muito - é muito fruto daqueles anos. Muito fruto daqueles anos todos. Os que plantaram são esses daí. Depois eu vou passar isso aqui prá quem? Para a turma do Quilombhoje, para o Cuti, para o Paulo Colina, para o Márcio Barbosa. Eles não têm livros: eu empresto. Eu tiro cópias para eles. O poema Protesto, do Carlos Assumpção, ninguém tinha. Eu tenho o poema.”. Entrevista com Oswaldo de Camargo concedida a Mário Augusto M. da Silva, São Paulo, 29 de julho de 2007. E ainda: "Uma coisa importante para mim foi encontrar um livro do Oswaldo de Camargo, chamado O Carro do êxito. É um livro de contos, mas foi o primeiro livro de literatura que eu comprei, numa livraria comum na praia de Santos, que falava das entidades negras de São Paulo. E também tinha uma coisa fundamental: ele escreve muito em primeira pessoa, a primeira pessoa de um negro. Aí eu vi a foto do autor e falei: "Puxa!" Foi um deslumbre para mim[...] O Oswaldo foi uma pessoa importantíssima como um elo de gerações. Sabia muito! Ele conheceu o Correia Leite quando ainda era novo. Então, para mim, esse livro foi um deslumbre, assim como o livro do Abdias, O negro revoltado, que eu também comprei em Santos. Foi também um grande deslumbre saber que já tinha havido congressos, jornais, Teatro Experimental do Negro e tantas outras coisas. Essas duas obras nortearam bem a minha vida nesse período." Entrevista com Cuti, concedida a Verena Alberti e Amílcar Pereira. Disponível Histórias do movimento negro no Brasil. Op. Cit. p. 92. 


\section{Encontros e antologias de escritores negros}

Importante recordar que os jornais da imprensa negra, desde a década de $1910^{6}$ traziam em suas páginas poemas e pequenos textos em prosa de autores dos grupos negros organizados em associações ou orbitando em torno delas e, ainda, consagrados no âmbito de uma Literatura Brasileira mais ampla (Cruz e Souza, Luiz Gama, algumas referências a Lima Barreto etc.). Essa prática se consolida, para além das publicações individuais, na burla à invisibilidade crítica e social da produção literária negra, que foi em diferentes momentos entre os anos 1960 e 80, efetivada pelas antologias poéticas, além dos jornais de associações do grupo negro, ou os Cadernos Negros, em São Paulo.

Entretanto, no que diz respeito ao ato literário e ideológico de juntar autores, prefaciá-los, organizar uma biobibliografia crítica sobre os mesmos, tendo como intuito oferecer uma amostragem de um certo tipo de produção, as antologias de Literatura Negra no Brasil encontram, em 1967, com Léon Gontram Damas, um ponto interessantíssimo, por ao menos três razões: 1)o organizador da Nouvelle Somme de Poésie du Monde Noir [Nova Reunião de Poesia do Mundo Negro] era, junto com Aimé Césaire e Leopold Sedar Senghor, um dos criadores do movimento estético da Negritude, em Paris, década de 1930; 2) e aquela antologia reunia poetas negros de diferentes partes do mundo, editados pela revista Présence Africaine; 3)tendo inclusa nela, autores negros brasileiros como Oswaldo de Camargo, Luiz Paiva de Castro, Natanael Dantas e Eduardo de Oliveira, entre outros, que são traduzidos e publicados nessa edição, conferindo-lhes (e à Literatura Negra no Brasil) um certo grau temporário de legitimação. ${ }^{7}$

6 Cf. MOURA, Clóvis \& Ferrara, Miriam N. Imprensa Negra, São Paulo: Imprensa Oficial do Estado, 2002 [1 ${ }^{\text {a }}$ ed. 1984].

7 De acordo com Oswaldo de Camargo, o contato de Damas com os escritores brasileiros se deu através da Associação Cultural do Negro. "Ele veio ao Brasil, Léon Damas veio ao Brasil e fez uma coletânea, uma antologia, de poetas[...]Quer saber onde estão os poetas?[...] Vá à Associação[...] A Associação era o grande tambor que repercutia tudo. Era muito respeitada! Nenhum estudioso de questões negras deixava de ir à Associação. Nenhum! "Quer saber onde...?" Era lá. Basta dizer o seguinte. Não é muito difícil entender não. [José] Correia Leite estava lá. 
Dez anos mais tarde, a editora Civilização Brasileira publica Ebulição da Escrivatura: Treze Poetas Impossíveis, autores cariocas negros, dentre os quais Éle Semog, atrelada ao Grupo Garra Suburbana. Em 1976, a editora Cooperativa de Escritores publica em São Paulo a antologia Ventonovo, com trabalhos de Arnaldo Xavier e Aristides Klafke, no esteio da literatura marginal da década de 1970. No lançamento da página "AfroLatinoAmérica", Oswaldo de Camargo edita para o jornal Versus um "Pequeno Mapa da Poesia Negra", onde arrola e discute o papel de diferentes escritores negros ao longo da história brasileira no século $\mathrm{XX}^{8}$. E ao longo dos anos 1980, a Literatura Negra não cessaria de se refletir e ser repensada por estudiosos?.

Em agosto de 1982, a Global Editora lança uma publicação premiada pela Associação Paulista de Críticos de Arte [APCA], como melhor livro de poesias do ano. "Fato inédito para antologias"10, assinalou Oswaldo de Camargo ao tratar de Axé: Antologia Contemporânea da Poesia Negra Brasileira, organizada pelo escritor paulista Paulo Colina.

Propósito semelhante encontra-se no trabalho, como antologista, de Oswaldo de Camargo. Em A Razão da Chama e $O$ Negro Escrito existe a preocupação com as ideias de continuidade e contemporaneidade do labor artístico negro. Como se afirma no

Correia Leite era uma espécie de guru. Era um pedaço de história. Naquele tempo já era.” Entrevista com Oswaldo de Camargo, concedida a Mário Augusto M. Da Silva, em São Paulo, 29 de julho de 2007. Colchetes meus.

8 "Onde está a Poesia Negra? Onde Lino Guedes? Os poetas da Imprensa Negra e das associações? Onde os continuadores dos anseios de Gervásio de Morais e de Cumba Júnior? E de Carlos Assumpção, que iniciou em 1958, o verdadeiro protesto negro na nossa poesia?[...] Eis que se inicia a fase de nos descobrirmos. Traçar o mapa, marcar o território de nossa herança poética, desconhecida e esparsa. Tentar fazer o que jamais se fará oficialmente: a coleta de nossa produção literária, o nosso clamor espalhado em jornais da imprensa negra marginal, nas revistas negras, recolher os inéditos, trazê-los, enfim, à tona. Tarefa prolongada e dura, quanto urgente e necessária. Nossa tarefa". Cf. Camargo, Oswaldo, "Pequeno Mapa da Poesia Negra", Versus, vol. 12, julho/agosto, 1977, p. 32. Sobre a seção Afro Latino América e a literatura negra do período, ver: Silva, Mário A. M. da. A Descoberta do Insólito. Op. Cit. pp. 441-482

9 BROOKSHAW, David. Raça e cor na literatura brasileira, Porto Alegre: Mercado Aberto, 1983; BERND, Zilá. Negritude e literatura na América Latina, Porto Alegre: Mercado Aberto, 1987; Idem. Introdução à literatura negra, São Paulo: Brasiliense, 1988; CAMARGO, Oswaldo de. O Negro Escrito: apontamentos sobre a presença do negro na Literatura Brasileira, São Paulo: Imprensa Oficial do Estado, 1987, entre outros.

10 CAMARGO, Oswaldo de. O Negro Escrito, Op. Cit. p. 100. 
prefácio da primeira coletânea: "Esta antologia[...] acaba revelando que o negro que escreve não é tão somente Luís Gama e Cruz e Souza. É - queremos aqui demonstrar - prosseguimento deles[...]"11 Cobre-se, então, desde o século XVIII até os últimos quartéis do XX para comprovar, como afirma Paulo Colina, que "Se não maior, o negro sempre foi um dos grandes temas da literatura brasileira. Sem ele, não teríamos, com certeza, a ficção que temos." 12

Os anos 1980 e 90 apresentam conjuntura favorável a uma visibilidade da Literatura Negra, especialmente no âmbito da Poesia. Além das edições regulares dos Cadernos Negros, os trabalhos avaliativos como Reflexões e Criação Crioula, ou as antologias de Camargo e Colina, existe ainda um movimento de circulação internacional e legitimação crítica nacional dessa produção marginal. A crítica literária Moema Parente Augel e o tradutor Johannes Augel serão os responsáveis, em 1988, pela edição da antologia bilíngue Schwarze Poesiel Poesia Negra, em alemão/português ${ }^{13}$ (mais tarde, editam Schwarze Prosa/Prosa Negra). No mesmo ano, Júlia Duboc publica Pau de Sebo: coletânea de poesia negra ${ }^{14}$. Quatro anos mais tarde, Zilá Bernd organiza Poesia Negra Brasileira: antologia ${ }^{15}$. Em 1995, a colaboradora dos Cadernos Negros Miriam Alves e Carolyn R. Durham editam Finally Us [Enfim nós], nos EUA, coletânea de textos de escritoras negras brasileiras em edição bilíngue portuguêsinglês, junto a uma longa análise crítica sobre o assunto, de sua autoria $^{16}$. No mesmo ano, o projeto bilíngue editado e organizado por Charles Rowell, da revista norte-americana de artes e letras afroamericanas e africanas Callaloo, da Universidade John Hopkins, publica um número especial sobre Literatura Afro-Brasileira e traz entrevistas, textos, desenhos e estudos de autores como Arnaldo

11 CAMARGO, Oswaldo de. A Razão da Chama, São Paulo: GRD, 1986, p. X. Cit., p.11

12 COLINA, Paulo. "Prefácio" In: CAMARGO, Oswaldo de. O Negro Escrito, Op.

13 AUGEL, Moema Parente(org.). Schwarze Poesie/ Poesia Negra, St. Gallen/Köln: Edition Diá, 1988. Schwarze Prosa/ Prosa Negra é publicada em 1993.

14 DUBOC, Júlia(org.). Pau de Sebo: coletânea de poesia negra, Brodowski: Projeto Memória da Cidade, 1988.

15 BERND, Zilá(org.). Poesia Negra Brasileira: antologia, Porto Alegre: AGE/IEL/IGEL, 1992.

16 ALVES, Miriam \& DURHAM, Carolyn R. Finally Us. Contemporary Black Brazilian Women Writers, Colorado: Three Continent Press, 1995. 
Xavier, Cuti, Miriam Alves, Paulo Colina, Abdias do Nascimento, Leda Martins, Ele Semog e outros ${ }^{17}$. São esforços engendrados ainda no final dos anos 1980, ganhando concretude na década seguinte.

\section{Discutindo a si mesmos}

No plano da autoanálise, em 1985, o Conselho de Desenvolvimento e Participação da Comunidade Negra de São Paulo ${ }^{18}$ publica o livro Reflexões: sobre a literatura afro-brasileira, de autoria do coletivo Quilombhoje. A origem do livro está na "Noite da Literatura Afro-Brasileira", realizada durante o III Congresso de Cultura Negra das Américas, em 1982, na PUC-SP. Ali foi lançada uma antologia pequena de textos, com 80 exemplares, de forma apostilada. O Conselho da Comunidade Negra, afirmava na apresentação do livro, que a publicação era uma forma de reconhecimento do Quilombhoje no campo literário, bem como uma forma do movimento negro se manifestar de maneira livre e independente.

Reflexões traz elementos que seriam marcas registradas do Quilombhoje: na capa, aparece o desenho de Márcio Barbosa, que se tornaria o símbolo do grupo. Três máscaras negras diferentes, dispostas de forma triangular, irmanadas por um livro. A outra marca, que perdurou durante muito tempo na série dos Cadernos Negros, são as fotografias dos autores presentes nos livros, na contracapa. Por fim, a discussão do coletivo face ao que se falava sobre o negro e a Literatura Negra.

17 ROWELL, Charles (org.). Callaloo. Baltimore, Maryland: The John Hopkins University Press, vol. 18, n. 03, 1995.

18 Órgão criado junto ao poder estadual, ligado ao PMDB e ao movimento negro, durante a vigência do governo de André Franco Montoro. Sobre o conselho, checar o livro de Ivair Augusto Alves dos Santos, baseado em sua dissertação de mestrado defendida na Unicamp, em 2001: O Movimento Negro e o Estado (1983-1987): o caso do Conselho de Participação $e$ Desenvolvimento da Comunidade Negra no Governo de São Paulo, São Paulo: Prefeitura Municipal de São Paulo/ Coordenadoria dos Assuntos da População Negra, 2007. 
[...] Quando o Quilombhoje foi criado, sua atuação não tinha sido delineada. A experiência com as discussões, Rodas de Poemas e outras atividades, a saída e entrada de pessoas, deu-nos uma perspectiva mais nítida. Resultado desse caminhar, este livro não se propõe a ser começo nem fim. É parte de uma luta que nos transcende, pois teve início muito antes e vai continuar depois de nós. Isso enquanto persistirem as pressões que fazem da nossa vida uma sub-vida. Portanto, não vamos escamotear a questão ideológica ligada à literatura nem tampouco reduzir esta àquela.

Um texto apresentado por Cuti em seminário do Centro de Estudos Afro Asiáticos é republicado, dois anos depois, sem alterações: "Literatura Negra Brasileira: Notas a respeito de condicionamentos", trabalho que visa passar em revista autores modernistas (adeptos do Negrismo) e autores negros contemporâneos ao Modernismo para pensar o papel do negro em ambos. Escritores sincrônicos ao autor do artigo, negros ou não, também são rapidamente analisados (Ferreira Gullar, Ruy Dias, Oswaldo de Camargo, Solano Trindade etc.) Condicionamento, portanto, no sentido do artigo, deve ser compreendido como regulagem, controle, imposição. Sejam as impostas pela sociedade brasileira ou as autoimpostas pelo criador negro, com quais este, se quiser ou puder, terá de lidar. De acordo com Cuti:

Blitz no sentimento negro é uma constante. Acusado de rancor, resta a alternativa de viver acuado em si mesmo, enquanto aprende as regras da vista grossa e do escamoteamento da expressão. Na pauta do permitido todos devem se esforçar para o sustento de todas as notas da hipocrisia nas relações raciais. [...] Hoje há um dado considerável na transformação, a presença dos descendentes, mais visíveis dos escravos. O texto escrito começa a trazer a marca de uma experiência de vida

19 Cf. QUILOMBHOJE. Reflexões, Op. Cit. pp. 13-14. 
distinta do estabelecido. A emoção - inimiga dos pretensos intelectuais neutros - entra em campo, arrastando dores antigas e desatando silêncios enferrujados. É a poesia feita pelo negro brasileiro consciente.

Este negro brasileiro consciente, enquanto escritor, de que fala o autor é um ser em crescendo, cuja oscilação histórica é patente no percurso da Literatura[Negra] Brasileira ${ }^{21}$. Ele se iniciaria com Cruz e Souza e Lima Barreto e de expressões atomizadas, culminando num projeto coletivo. Projeto esse que, enquanto questão ideológica pareceria estar bem resolvido; no âmbito do plano estético, entretanto, apresentava rusgas significativas. O debate se dá em torno da qualidade da produção literária negra. Como apresenta rapidamente o autor:

20 CUTI. "Literatura Negra Brasileira: Notas a respeito de condicionamentos" In: QUILOMBHOJE. Reflexões, Op. Cit. p. 16.

21 "Lino Guedes, um dos primeiros poetas negros a revelar em seus trabalhos a busca de uma identidade em nosso século, abriu e se manteve com frequiência na linha do lamento, extravasados em versos aproximados do cordel. O flagelo da escravidão ocupou lugar predominante em sua obra.[...] Mostra ainda comportamentos perante a temática da escravidão e suas conseqüências que são presentes, com as naturais marcas de época, na poesia negra hoje. [...]A visão fatalista da história, além de ser um ensinamento propalado pelo branco durante muito tempo, situa o criador fora da zona crítica, reveladora das reais causas da espoliação. A constatação do flagelo por si só, pouco avança o processo de conscientização, e acaba por estar conforme ao paternalismo das elites. [...]Também a presença do movimento apelativo à religião, tanto para explicar quanto para amenizar as amarguras, continua hoje marcando os textos. Achar que Deus nos esqueceu é um desencanto que a religiosidade, católica, sobretudo, nos legou diante da exploração do homem sobre o homem. [Crítica ao livro de estréia de Oswaldo de Camargo, 1959, Um homem tenta ser anjo] [...] Uma outra característica da obra de Lino Guedes, insistente em nossos dias, é o cuidado de não revelar-se em profundidade, juntamente com a consciência de uma identidade grupal. Tanto Oswaldo de Camargo[...] quanto de Eduardo de Oliveira[...] estreavam com livros onde suas vivências de negros estão submersas em queixumes. Evoluíram, sem dúvida[...] Solano Trindade, a figura mais conhecida da poesia negro-brasileira, antecedeu os dois autores citados. A obra de Solano, com Poemas de uma vida simples e Cantares ao meu povo deu o grande salto político-poético, apesar do reduzido alcance psicológico de seu trabalho.[...]É de 1956, o surgimento, no meio das reuniões de debate da questão racial, do poema "Protesto", de Carlos Assumpção, marcando assim um dos grandes lances de contundência na poesia negra que muitos ainda hoje estranham e evitam. "Piedade não é o que eu quero"... "Eu quero coisa melhor/ Eu não quero mais viver/ No porão da sociedade..." [...] Este poema[...] marca uma ruptura ou propõe que ela seja feita - tendo em vista a pertinência de condicionamentos que ainda confundem o literato negro." Idem, Ibidem, pp. 20-22,. 
Em 1978 surgiram os "Cadernos Negros", primeira tentativa de agrupamento, de literatos e aspirantes, em torno de uma publicação coletiva, já em seu quinto número alternado poesia e prosa. Os nomes aumentam e a aproximação se efetua, e com ela, os debates. Surge a questão da qualidade: conflito! É o momento da busca dramática do reconhecimento público que compense tantos sacrifícios (o rompimento com a autocensura, o custeio das edições ou peregrinações às editoras, e também venda dos livros).

A discussão sobre a qualidade, que aparece de maneira elegante no trecho acima, foi bastante agressiva em meio a esse coletivo de escritores. O suficiente para 1)quatro anos após a criação da série Cadernos Negros, três de seus membros, inclusive um fundador, a deixassem (Abelardo Rodrigues, Paulo Colina e Oswaldo de Camargo, denominados, doravante por um certo tempo, pejorativamente como $O$ Triunvirato); 2) esse debate se estendesse para mais outra produção reflexiva (Criação Crioula, que se discutirá na sequência), com tintas mais fortes e da qual o Triunvirato não participaria; 3)retornasse num livro situacional da Literatura Negra no contexto brasileiro (O Negro Escrito, de Oswaldo Camargo); 4) fosse apontada como um fator limitante pela crítica literária à eficácia produtiva da Literatura $\mathrm{Negra}^{23}$; 5)e, por, fim, continuasse viva, de certa forma, nos dias atuais ${ }^{24}$.

\section{Idem, Ibidem, p.22}

23 “[...]Alguns autores, como Cuti e Jamu Minka, seus fundadores, participam desde a primeira edição, enquanto outros, como Míriam Alves, Ele Semog e Carlos Limeira, colaboraram em várias edições, além de publicarem outras obras isoladamente. Eduardo de Oliveira e Oswaldo de Camargo, representantes da velha guarda, produziram para os números 1 e 3, desistindo depois por não concordarem com o sistema de seleção dos textos a serem incluídos nas antologias. Outros dois poetas que contribuíram nos primeiros Cadernos e que posteriormente preferiram ir para a publicação individual foram Oliveira Silveira e Paulo Colina. [...]Estas antologias, sobretudo nos últimos anos, têm revelado uma importância mais social e cultural do que propriamente artística. $O$ que efetivamente tem ocorrido é que o critério editorial parece estar sendo o de dar oportunidade a jovens poetas inéditos que mantêm a poesia muito próxima dos referentes imediatamente reconhecíveis sem a mediação da linguagem simbólica, sem a qual não há poesia, mas um mero extravasar de sentimentos. $O$ tom de panfleto, dominante em muitos trabalhos, sufoca a linguagem poética que, construindo-se com uma intencionalidade ideológica muito precisa, acaba configurando-se como repetitiva e redundante. $O$ que foi o ato criador nos primeiros poetas 
Entrementes, em 1982, quando aquele texto foi escrito, a discussão estava relativamente situada em torno das articulações da Literatura Negra com os movimentos sociais e à lida do escritor com os entraves do condicionamento. Segue-se ao texto de Cuti uma tentativa de pensar a necessidade de uma produção literária negra infantojuvenil $^{25}$; uma nova discussão sobre a questão dos condicionamentos, com uma crítica ao livro de David Brookshaw ${ }^{26}$; uma apresentação de série de poemas de autores negros, explicitando a característica do protesto e da consciência crítica $^{27}$; e também algumas "Questões sobre a Literatura Negra", por Márcio Barbosa.

Nesse texto em particular, Barbosa usa aspectos do pensamento de Frantz Fanon com a intenção de demonstrar que: 1) a Literatura Negra existe em larga razão de haver sua contraparte branca, o que retoma a famosa expressão daquele pensador martinicano de que o foi o branco que criou o negro; 2) criada numa posição subalterna e oprimida, à Literatura Negra resta o desenvolvimento de uma autoconsciência, fundada no desenrolar da luta histórica do grupo negro contra sua condição de oprimido. ${ }^{28}$

do grupo Quilombhoje torna-se ritual; o que foi sacrílego se banaliza" Cf. BERND, Zilá. Negritude e Literatura na América Latina, Op. Cit., pp. 129-30. Grifos meus.

24 “[...]Foi um lance muito bom. Foi um lance que obrigou as pessoas a escreverem, a se olharem de novo como escritores. Os mais velhos, sem dúvida, eram o Eduardo de Oliveira e eu.[...]Mas eu sempre tive uma crítica muito forte, aos Cadernos, no começo. Os Cadernos surgiram para colocar textos. Tudo bem. Mas textos sem passar pelo crivo de nada. Punha texto quem pagasse. No começo, era mais ou menos assim. Pagava, punha. E eu achava que na altura que nós estávamos já, depois... bons autores negros, autores com certa tarimba, era necessário educar esse pessoal, que pega um poema da gaveta e fala: "Eu também sou poeta!" O que era necessário, era fazer um Caderno que contemplasse, sobretudo, as pessoas que estavam iniciando. Mas, eu fui vencido. Fui vencido e saí dos Cadernos. Não comecei a publicar mais.[...]Não havia discussão de textos, não havia nada. Eu estava sempre pedindo isso, que nós fizéssemos alguma coisa... Que podia ser, ao mesmo tempo, uma espécie de escola.[...]até que o Quilombhoje acordou, os Cadernos acordaram e começaram a fazer a triagem também. Aquilo que eu propunha, depois de tanto tempo, eles perceberam que era necessário, de fato. Daí começaram a fazer. Hoje em dia é triado; hoje em dia, os Cadernos têm, passam por leituras, não sei o quê..." Entrevista de Oswaldo de Camargo, concedida a Mário Augusto M. Da Silva, em 29/07/2007, em São Paulo.

25 RIBEIRO, Esmeralda. "Literatura Infanto-Juvenil” In:QUILOMBHOJE. Reflexões,

Op. Cit.

26 FERREIRA, José Abílio. “Considerações à cerca de um aspecto do fazer literário ou de como um escritor negro sofre noites de insônia” In: QUILOMBHOJE. Reflexões, Op. Cit.

27 MINKA, Jamu. "Literatura e Consciência" In: QUILOMBHOJE. Reflexões, Op. Cit.

28 BARBOSA, Márcio. "Questões sobre a Literatura Negra" In: QUILOMBHOJE. Reflexões, Op. Cit., p. 50. Grifos meus. 
A questão de Barbosa pode remeter imediatamente à discussão de Zilá Bernd: em que momento surge uma Literatura Negra? Tanto para aquela crítica literária como para esse escritor, o grau zero da produção negra é a consciência social do ser negro, desembocando na ideia de negritude. Em Barbosa, o argumento se sofistica, alcançando a espinhosa discussão da dupla consciência do escritor negro - desenvolvido do repertório fanoniano sobre a dupla consciência do intelectual colonizado.

O corolário dessa afirmação é que o caminho para o escritor negro ser um agente social de mudança é reconhecer a sua condição. Todavia, no texto de Barbosa, há uma aposta muito grande, neste momento, que é dada quase como fato consumado: o reconhecimento dessa condição social garantiria um conteúdo revolucionário, mesmo que a forma criadora não se alterasse. A consciência do escritor negro é para este autor, portanto, precede os problemas de sua forma de expressão, em seu campo de atuação.

Ainda em Reflexões, Míriam Alves, poeta paulistana, continua o debate de Barbosa e Cuti, mas fixando-se na concretude de poemas contemporâneos ${ }^{29}$. Oubi Inaê Kibuko, por sua vez, perfaz um itinerário pessoal de sua origem familiar até conhecer o coletivo Quilombhoje. Seu texto objetiva mostrar o nascimento de sua conscientização como militante e escritor negro ${ }^{30}$. O tema é retrabalhado no último e mais curto texto da coletânea, de Sônia F. Conceição, com uma discussão interessante, mas não aprofundada, sobre os significados de ser negro ${ }^{31}$.

Se Reflexões é uma obra coletiva do Quilombhoje, com uma base discursiva relativamente homogênea e distribuída entre debates teóricos e depoimentos de um quotidiano do [escritor] negro, a próxima coletânea de texto a ser analisada é um exemplo de multiplicidade de visões, por vezes conflitantes, sobre a confecção literária negra. Parte-se, no entanto, do princípio que ela exista - e há muito tempo - expressa pela concretude de sua produção. Não à toa, a

29 ALVES, Míriam. “Axé Ogum” In: QUILOMBHOJE. Reflexões, Op. Cit.

30 KIBUKO, Oubi Inaê. "1955-1978: 23 anos de Inconsciência" In: In: QUILOMBHOJE. Reflexões, Op. Cit.

31 CONCEIÇÃO, Sônia F. "Ser Negro, Povo, Gente: Situação de Urgência" In: QUILOMBHOJE. Reflexões, Op. Cit. 
capa de Criação Crioula, Nu Elefante Branco é a disposição aleatória de vários livros de poetas e prosadores negros, iniciando-se com autores do século XIX até a contemporaneidade de 1985.

Criação Crioula é o resultado do I Encontro Nacional de Poetas e Ficcionistas Negros. Publicado pela Imprensa Oficial do Estado de São Paulo, em 1987, durante a vigência do governo de André Franco Montoro e realizado entre 06 e 08 de setembro de 1985, na Faculdade do Ipiranga, na capital paulista. As motivações para o encontro, segundo sua Comissão Organizadora, seriam as seguintes:

É de 1983/84 a ideia de realização de um encontro de escritores Negros de âmbito nacional. Era necessidade de se fazer uma avaliação profunda da Produção Literária Negra recente e seu redimensionamento com a produção do passado - Luiz Gama, Cruz e Sousa, Machado de Assis, Lima Barreto, Lino Guedes, Solano Trindade e outros. Pretendia-se também a revisão crítica do caráter etnocêntrico da indústria cultural traduzida em "bloqueio editorial" ou em solidariedade "negrófila". Outro objetivo era o de situar essa mesma produção dentro dos espaços explosivos dos movimentos políticos Negros de hoje no Brasil. Estas foram algumas das principais motivações do Encontro. As articulações datam precisamente de 1984, quando os grupos Quilombhoje (São Paulo) e Negrícia (Rio de Janeiro) aventaram a possibilidade de se reunirem para discussão de propostas e perspectivas da Literatura Negra no Brasil. [...] Na ocasião do evento intitulado Perfil da Literatura Negra: Mostra Internacional, em São Paulo, no mês de abril/1985, houve uma reunião/almoço na qual estavam presentes 17 escritores dos estados de São Paulo (Arnaldo Xavier, Míriam Alves, Cuti, Zenaide, Valdir Floriano, Abelardo Rodrigues, Oswaldo de Camargo, Oubi Inaê Kibuko e Roseli Nascimento), Rio de Janeiro (Selma Maria da Silva, Éle Semog e Hermógenes Almeida S. Filho), Bahia (Jônatas C. Da Silva e Edu 
Omo Oguiam) e Rio Grande do Sul (Oliveira Silveira e Paulo Ricardo de Moraes). ${ }^{32}$

A edição é composta de 20 textos e uma sessão parcialmente transcrita de debates, de que reproduzem-se excertos nas notas de rodapés seguintes, entre pelo menos 15 participantes. É particularmente interessante atentar aos tópicos principais dessa discussão: 1)o problema da editoração e do escritor; 2)Literatura Negra e analfabetismo; 3)partidos e revolução; 4) Literatura Negra e Estado; 5)Literatura Negra e sua produção marginal. Aliás, este último, junto com as possibilidades e reticências de relacionamento com o Estado ocupam vários momentos de preocupação transcrita dos escritores, àquela ocasião, como pode ser sintetizado no último momento do debate a seguir:

[Márcio Barbosa]: O Cuti falou "sonho do escritor em ser empresário". É um conflito. Nós estamos dentro dele. É um conflito que, se não existir a solução a curto prazo, desconfio que não iremos chegar nos dez anos, previsto pelo [Éle] Semog, para a explosão da Literatura Negra. Despendemos muita energia para fazer isto. Se não houver resultado a curto prazo, não sei se esta energia não irá se esgotar e não teremos mais escritor negro para o público que está pintando.[...] Aí entra uma coisa interessante: o nosso relacionamento com o Estado que o Arnaldo [Xavier] fala, talvez possamos ir por aí. Há um medo de se relacionar com o Estado, que é extremamente justificado. O Estado visa o interesse do Estado. Nem

32 I Encontro de Poetas e Ficcionistas Negros Brasileiros(org.). "Simplesmente Histórico" In: Criação Crioula, Nu Elefante Branco, São Paulo: Imesp, 1987, p. 05. A Comissão ainda lembra que "Num clima de bastante discussão, ficou de consenso a escolha de dois temas básicos: 1)Intervenção dos Poetas e Ficcionistas Negros no Processo de Participação Política; 2)Avaliação Crítica da Produção Literária dos Últimos Dez Anos [...] Igualmente, de maneira polêmica, definiu-se o caráter político e ideológico do Encontro, o qual deveria ser efetuado de forma autônoma e independente, isto é, sem verbas oriundas do poder público ou privado (aspecto este que também serviu para explicar a dissidência anteriormente citada)" (p. 06, grifos meus) A dissidência a que se refere a Comissão é a de um escritor, Abelardo Rodrigues, que não concordava com os termos do encontro. 
sempre está a nosso favor. Mas acho que podemos estabelecer um certo relacionamento, sem perder nossa autonomia. O Arnaldo falou "que não estamos aqui para pedir reconhecimento". Gostaria de refutar: nós estamos querendo o reconhecimento sim, queremos o reconhecimento pelo menos da nossa comunidade.",33

Dada a multiplicidade de temas e autores em Criação Crioula, é necessário resumir aqui três elementos sempre articulados, mais frequentes e melhor desenvolvidos em todos eles: 1)o problema da marginalidade da Literatura Negra; 2)o relacionamento com o Estado; 3)e a questão da qualidade. Todos os textos, com maior ou menor empenho, farão uma recuperação de prosadores e poetas negros ao longo da história literária, ressaltando-lhes ou denunciandolhes aspectos positivos e negativos. O momento político da Nova República e a situação de diferentes movimentos negros neste contexto também é algo que não escapa à maioria das reflexões.

No entanto, vale atentar que os acontecimentos políticos sintetizados em 1984 - as Diretas Já, as campanhas pela redemocratização e o voto direto paras as eleições presidenciais - não sofrem uma análise mais detida por parte desses escritores. Teria, como explicita o debate de Abílio Ferreira, abaixo, o negro estado ausente (ou se ausentado) deste momento também? Ou o vivenciado sob uma ótica particular?

Ademais, tudo o que se lê sobre a década de 60 faz crer que a questão racial não existiu naquele período. Relatos e análises apaixonadas sobre o CPC e a UNE, sobre o PCB, sobre o período 45-64, a respeito do qual já se disse que foi um tempo em que o país estava irreconhecidamente [sic] inteligente, quando havia uma "política externa independente", "reformas estruturais", "libertação nacional" e "combate ao imperialismo e latifúndio" não tocam na questão racial; a movimentação

33 I Encontro de Poetas e Ficcionistas Negros Brasileiros(org.). "Palavras "Jongadas" de Boca em boca (gravação dos debates)" In: Criação Crioula, Nu Elefante Branco, Op. Cit., p. 29 
operária, começada em 1950 e que recrudescia paulatinamente, não incluía os negros em especial.[...]Ocorre que há uma insistência em manter a questão racial, como a de outras minorias menos numerosas, diluída no gigantesco espectro da luta de classes. Um exemplo: em maio deste ano, por ocasião da Mostra Internacional de Literatura Negra, realizada no Centro Cultural São Paulo, o senhor Secretário de Cultura, Gianfrancesco Guarnieri, um dos expoentes do famoso Teatro de Arena[...] afirmou para o auditório abarrotado algo como "a partir do momento em que estiver solucionada a questão sócio-econômica, a racial também o será automaticamente. ${ }^{34}$

O trabalho de Ferreira traz muitos outros pontos interessantes para discussão. Por exemplo, a perspicaz observação que faz o autor sobre a Literatura Negra em descompasso com a vanguarda ${ }^{35}$. Ou sobre a invisibilidade, para a crítica especializada, da experiência negra em momentos recentes da história cultural e política brasileira, em particular nos anos 1970, reafirmando, mais uma vez, sua marginalidade. $^{36}$

34 FERREIRA, J. Abílio. "A Formação de um conceito nacional” In: I Encontro de Poetas e Ficcionistas Negros Brasileiros (org.). Criação Crioula, Nu Elefante Branco, Op. Cit., p. 75. A expressão de um "Brasil irreconhecivelmente inteligente" está presente no ensaio clássico de Roberto Schwarz, "Cultura e Política: 1964-1969”, em O Pai de Família e outros ensaios, São Paulo: Paz \& Terra, 1974.

35 "Certo é que a produção artística e cultural negra esteve sempre em descompasso com as estéticas que costumam dar o tom das épocas. E isto é significativo. Enquanto os modernistas estavam buscando dados populares a fim de contrapor, na forma e no conteúdo, os rigores parnasianos, os escritores negros estavam fazem sonetos. Enquanto os concretistas propunham uma adaptação da poesia com os novos tempos e sintonizavam-se com os tropicalistas da MPB, os escritores negros, no mínimo, nem se deram conta da discussão em torno do comportamento artístico 50/60 em face da afirmação cada vez mais veemente do processo de industrialização. Os escritores negros, como artistas em geral, estava, tratando de questões mais prementes que só a eles interessava." Cf. FERREIRA, J. Abílio. "A Formação de um conceito nacional" Op. Cit., pp. 74-75.

36 Idem, Ibidem, pp. 76-77. Há fundamento na crítica, uma vez que um livro referencial sobre Imprensa Alternativa dos anos 1970, de Bernardo Kucinski, não registra, nem mesmo em sua última edição revista e ampliada algo sobre a Imprensa Negra do período, de jornais como Jornegro ou Árvore das Palavras. Mencionará apenas a seção Afro-América-Latina do jornal Versus. Cf. KUCINSKI, Bernardo. Jornalistas e Revolucionários nos tempos da imprensa alternativa, São Paulo: EDUSP, 2003 
Essa invisibilidade histórica é retomada por Míriam Alves, poetisa e colaboradora assídua dos Cadernos Negros/ Quilombhoje. A crítica recai sobre um aspecto da esquerda política, momento de clandestinidade, exílio e produções marginais também para o grupo negro. Para a historiografia da esquerda do período, no entanto, a experiência negra é ausente desse processo, ou subsumida na de cunho mais geral. A Literatura, o Teatro, a Imprensa Negra, então, seriam atos políticos de memória, para a autora, face às injustiças históricas. Em seus dizeres:

Ressalto nesta produção o ato político. Falo em atitude política não para designar passeatas de ficcionistas e poetas negros, exigindo seus direitos à publicação e circulação, exigindo a criação livre, permeada por sua vontade e inspiração, ou ainda exigindo reconhecimento dos órgãos públicos (secretaria disto ou daquilo), ou ainda reclamando suas entradas nos bares acadêmicos fechados (livrarias e editoras), onde somos literalmente barrados e discriminados por trás de discursos de má qualidade, subliteratura e desinteresse dos leitores. Não é deste ato político, que não fizemos, que falo. Falo do ato político que praticamos, escrevendo-nos em nossa visão de mundo.[...] Nos tempos não tão idos assim, todos nós brasileiros criadores de artes éramos obrigados a esconder nossa criação na gaveta e nos tornarmos artistas gaveteiros, ou desengavetar e tornarmo-nos exilados. Neste tempo, a nossa produção de negros artistas engavetou-se. Mais tarde, desengavetou-se na forma de livrinhos mimeografados, distribuídos nos botecos da vida, onde a esquerda tramava a revolução cultural. Aí nossos livrinhos foram recusados várias vezes (a esquerda nos olhava com seus olhos canhestros).,"37

37 ALVES, Míriam. "O Discurso Temerário” In: I Encontro de Poetas e Ficcionistas Negros Brasileiros (org.). Criação Crioula, Nu Elefante Branco, Op. Cit., p. 84. 
Subjaz a problemática do reconhecimento social e literário, como forma estratégica de sobrevivência de um projeto a longo prazo. Nas palavras de Éle Semog [Luiz Carlos Amaral Gomes], então membro do coletivo Negrícia:

A necessidade de nos agregarmos em grupos como o Quilombhoje, Palmares, Capoeirando, Negrícia, respondeu por um período pelos livros coletivos, pelas antologias. Esta prática tem que evoluir, porque o discurso do Estado mudou. É inconcebível que os trabalhos coordenados pelo Quilombhoje sejam financiados pelos próprios autores, após oito persistentes anos de prática e produção literária. É um despropósito da cultura nacional e para o povo brasileiro que a República Popular de Angola reconheça e financie o trabalho de 50 poetas brasileiros (livro Tetos de Aurora nos Punhos), de diversos Estados do Brasil, dentre os quais Oliveira Silveira, Oswaldo de Camargo, Cuti, Paulo Colina, José Carlos Limeira, Delei de Acari, Míriam Alves. Embora com grossura da omissão do nome de outros escritores, são nomes que sem dúvida alguma deveriam constar no planejamento anual dos senhores editores[...] Ora, estamos no Primeiro Encontro de Escritores Negros, em São Paulo, somos os próprios, e daqui teremos que arrancar soluções diferentes de nossa prática de militantes do Movimento Negro e das entidades negras. Nesse encontro temos que criar uma entidade de atuação nacional e internacional que não seja menor que um Centro Brasileiro de Literatura Negra, ou um 'instituto', ou uma 'união'. Esta entidade deve agregar os escritores negros, financiar e distribuir as suas obras, resguardados, evidentemente, alguns princípios inerentes à literatura universal e à dignidade dos povos.[...] Se por um lado carecemos de um Centro, um Instituto, por 
outro, mais urgente, carecemos também de uma editora e de uma gráfica. ${ }^{38}$

\section{Mostra e Perfil da Literatura Negra}

Os balanços efetuados pelos escritores negros e defensores da ideia de uma literatura negra são sinais de uma reflexão à quente sobre o estado de sua arte em compasso com o momento vivido. Isso implicou não apenas referenciar nessas obras de debate mas, também, participar de eventos como os ocorridos em 1985 e 1986, que se tornaram particularmente notáveis para a produção literária negra, pelo fato de que foram capazes de alçar um público diferente da produção endógena do grupo: a Mostra Internacional de São Paulo - Perfil da Literatura Negra (1985, sediada no Centro Cultural de São Paulo) e a III Bienal Nestlé de Literatura (1986, no Centro de Convenções Rebouças).

Ambos promoveram o encontro dos escritores negros com seus críticos, além de um público leitor mais amplo. É possível medir seus alcances pelas matérias de periódicos, tanto do Jornal do Conselho da Comunidade Negra de São Paulo como O Estado de São Paulo, Folha de São Paulo e Jornal da Tarde, no período. Uma das primeiras notícias sobre a Mostra Internacional de São Paulo - Perfil da Literatura Negra foi publicada no caderno Ilustrada da Folha de São Paulo, semelhante a um evento de coluna social, conferindo um caráter oficioso ao fato: "MÁRIO COVAS e o secretário municipal de Cultura Gianfrancesco Guarnieri convidam para o coq de abertura da Mostra Internacional de São Paulo - Perfil da Literatura Negra, dia 20 de maio, no Centro Cultural São Paulo." ${ }^{\text {"39 }}$. Dois dias depois, o evento é tratado de maneira mais substancial no mesmo jornal:

38 SEMOG, Éle. "A Intervenção de Poetas e Ficcionistas Negros no Processo de Participação Política" I Encontro de Poetas e Ficcionistas Negros Brasileiros (org.). Criação Crioula, Nu Elefante Branco, Op. Cit., pp. 142-143 e 145.

39 MIRANDA, Tavares de. Folha de São Paulo, Ilustrada, 17 de maio de 1985, p. 38. 
Durante a semana inteira, será a vez da intelectualidade negra do Brasil, Estados Unidos, África e América Central botar o preto no branco. De amanhã até o próximo domingo, o Centro Cultural São Paulo[...] será o palco dos debates do ciclo "O Perfil da Literatura Negra", uma iniciativa da Secretaria Municipal de Cultura. Entre os debatedores, uma estrela: o romancista norte-americano James Baldwin, 61, autor de "Giovanni". Mas estarão presentes também o herói angolano José Luandino Vieira, 50,[...] o moçambicano José Bernardo Honwana, 43,[...] e o senegalês Sembène Ousmane[sic], 62, [...] - todos lançados no Brasil pela Editora Ática.[...] $\mathrm{O}$ fórum será aberto amanhã pelo prefeito Mário Covas, com a presença do secretário Gianfrancesco Guarnieri e diversos embaixadores de países africanos, mas o debate promete esquentar mesmo é a partir de terça-feira, com a discussão de temas como "A Literatura Negra como forma de resistência", a partir de 20h30; "A recodificação do Mundo pelo Negro na Diáspora Através da Literatura" (quarta, mesmo horário); "O Estereótipo do Negro nos Meios de Comunicação" (quinta, a partir das 19horas); "Negritude, Conceitos e Caminhos" (sábado, começando às 10 horas da manhã) e "O Personagem Negro na Literatura" (às 15h30); e fechando o ciclo, "A Literatura Africana PósIndependência" (domingo, 10h da manhã). ${ }^{40}$

A reportagem mensura o evento como algo de proporção grande e dá maior destaque aos escritores estrangeiros. Além de Baldwin, traduzido ao longo dos anos 1960 e 80 no Brasil, os lusófonos (Vieira e Honwana) e o senegalês Sembène, publicados na

40 Em debate a Literatura Negra. Folha de São Paulo, Ilustrada, 19 de maio de 1985, p. 75. Baldwin foi traduzido no Brasil com os romances Numa terra estranha [Another Country], em 1965 pela editora Globo e Giovanni [Giovanni's Room], em 1981, pela Abril. Luandino Vieira inaugurou a coleção Autores Africanos com A vida verdadeira de Domingos Xavier [1979], da qual participam Honwana [Nós matamos o cão tinhoso, 1980] e Sembène [A ordem de pagamento, 1984]. Honwana foi alto funcionário do governo de Moçambique e Sembène é considerado o pai do cinema africano, a partir do filme La noire de [1966]. Todos os três últimos lutaram pela independência de seus países, além de Baldwin ter sido um notório ativista antirracista estadunidense. 
Coleção Autores Africanos da Editora Ática, a partir de 1979. Todavia, em se tratando de um debate sobre literatura negra brasileira, onde estariam os escritores negros nacionais para discutir o assunto? O autor do texto na Folha parece não se importar com isso, mas não deixa de notar algo que julga singularmente importante:

\begin{abstract}
Nem todos os debatedores, pelo menos entre os brasileiros, são negros, casos de professores como Antônio Cândido, Leo Gilson Ribeiro, Otávio Iam ni e outros. Guarnieri, também um dos debatedores, considera a "realidade multi-racial brasileira" ideal para um ciclo de debates.[...] Espera-se que sim, embora os temas propostos pareçam sugerir muito mais uma série de quiproquós acadêmicos, a serem tratados com o habitual sociologuês. Se isto se confirmar, a discussão sobre "o papel do negro"continuará em branco. [...] A esperança está na experiência dos escritores africanos convidados $[\ldots]^{41}$
\end{abstract}

Parte daquela esperança frustrou-se, dado $o$ não comparecimento de James Baldwin e Luandino Vieira ao evento, em função de outros compromissos em seus países ${ }^{42}$. E nada mais foi escrito, no jornal, sobre Sembène ou Honwana, apesar da importância de ambos. Contudo, os debates se deram no primeiro dia, especialmente entre angolanos (Manoel Rui e Adriano Botelho), o crítico inglês David Brookshaw, o poeta negro estadunidense Haki Madhubuti e o escritor brasileiro Adão Ventura. De acordo com a reportagem, na entrevista coletiva, todos debatendo a tentativa de uma definição da ideia de Literatura Negra, o seu papel antirracista, a tarefa do escritor defensor dessa estética (luta contra a estrutura racista e a favor de um processo global de descolonização) ou, ainda, sobre as considerações em torno de Machado de Assis como autor negro de literatura negra (papel que lhe é negado na fala de

41 Idem, Ibidem.

42 A Literatura Negra define seu papel. Folha de São Paulo, Ilustrada, 21 de maio de 1985, p. 34 
Brookshaw). O jornal $O$ Estado de São Paulo, reportando o evento consegue fornecer mais informações sobre a presença dos escritores especialmente os estrangeiros - e algo dos debates em que se envolveram:

Com o auditório lotado, o secretário municipal de Cultura, Gianfrancesco Guarnieri, instalou no Centro Cultural São Paulo o Perfil da Literatura Negra - Mostra Internacional de São Paulo.[...]Hoje os intelectuais brasileiros e estrangeiros convidados para participar do congresso discutem "Literatura e identidade". Integra a mesa o escritor, poeta e ministro da Cultura da Costa do Marfim, Bernard Dadié, um dos precursores dos movimentos negros junto com outros dois intelectuais igualmente importantes, Leopold Sedar Senghor e Aimé Césaire. Além dele, participam o escritor caboverdiano Manuel Faustino, os brasileiros Muniz Sodré e Maria Aparecida Santilli, o norte-americano Michael Michel e o moçambicano Rui Nogar. Numa segunda etapa, o mesmo tema reunirá, entre outros, o angolano Manuel Rui Monteiro, o venezuelano José Marcial Ramos Guedez, Simone Scharwarbart (de Guadalupe), Alex La Guma (da África do Sul) e os brasileiros Helena Theodoro e Wanderley José Maria. ${ }^{43}$

As críticas e desconfianças dos escritores negros brasileiros, com relação à sua invisibilidade e tratamento da política cultural do Estado, apontadas especialmente em Criação Crioula se justificam com os fatos selecionados pelas matéria de jornal. Não menos importante que o investimento para trazer escritores estrangeiros construindo assim uma importante perspectiva da diáspora africana pelo mundo ${ }^{44}$ - e situar o debate sobre a produção literária negra -

43 A Literatura Negra e a resistência dos povos. O Estado de São Paulo, 22 de maio de 1985 , p. 13.

44 “[...]O embaixador de Togo no Brasil, Djababou Nana, disse que o evento falava ao coração de todos os companheiros e que a vinda desses irmãos era uma conquista para um mundo melhor.[...] estão expostas obras literárias como Chão de Exílio, de Antonio Cardoso (escritor 
por negros e não-negros - seria fazer representar e ouvir os escritores negros brasileiros sobre o assunto. Embora o programa do evento tenha sido elaborado pela intelectual negra Thereza $\operatorname{Santos}^{45}$, poucas vezes isso é mencionado (cedendo lugar aos nomes oficiais do secretário de Cultura, Guarnieri, do governador do Estado, Franco Montoro ou mesmo do prefeito Covas). Isso fica patente em outra matéria do jornal, onde há o fornecimento de mais informações sobre a participação brasileira.

[...]A brasileira Teresa Santos, organizadora principal do evento, abriu a coletiva falando da importância desta mostra internacional, especialmente para os escritores negros brasileiros que não conseguem publicar suas obras a não ser no âmbito da publicação independente. Teresa Santos afirmou ainda que não adianta esconder, a discriminação no Brasil convencionou que "o negro não pensa". E sendo assim sua produção literária não interessa às editoras. Citou apenas alguns escritores negros que conseguiram furar este "cerco", como Adão Ventura e Paulo Colina. Mas reconheceu que o panorama começa a mudar, com o interesse que a editora Roswitha Kempf vem mostrando pela produção negra e que a editora Ática já provou, editando no Brasil inúmeros romances africanos. [...]Teresa Santos, em seguida, apresentou os escritores presentes: os brasileiros Adão Ventura, Paulo Moraes, Jônatas Conceição da Silva (de Salvador) e Oliveira Silveira (de Porto Alegre); José Marcial Ramos Guedes, da Venezuela; Maximilian

angolano), Black Gods and Kings, do nigeriano Robert Farris Thompson e uma seleção de textos sobre o período pós independência de São Tomé e Príncipe, de 1975 a 1977[...]”. Cf. Literatura Negra: aberta a discussão. O Estado de São Paulo, 21 de maio de 1985, s/p.

45 "Na Secretaria Municipal de Cultura, na gestão de Gianfrancesco Guarnieri, consegui realizar alguns projetos voltados para a periferia da cidade, e dois deles foram muito importantes para mim: "O I Perfil da Literatura Negra - Mostra Internacional de São Paulo", em 1985, com a participação de escritores de Moçambique, Angola, Nigéria, Cabo Verde, Venezuela, Inglaterra, Uruguai, América do Norte e Portugal. Este projeto deu um panorama do que era produzido na literatura com temática negra, feita por brancos ou negros. A frequência em oito dias de palestras e debates foi muito boa, com uma média de 200 pessoas por debates.[...]" Ver: SANTOS, Thereza. Malunga Thereza Santos: a história de vida de uma guerreira. São Carlos: Edufscar, 2008, pp.100-101. 
Laroshe [sic], do Haiti; Manoel Ruy Monteiro e Adriano Botelho de Vasconcellos, de Angola; e o americano Don Lee, que assina Haki R. Madhubuti. Presentes também, como convidados do congresso, o professor inglês David Brookshaw e a professora gaúcha Zilah Bernd.[... $]^{46}$

Desta maneira, a carta enviada a $O$ Estado de São Paulo por um leitor e talvez escritor negro ganhasse concretude prática no trecho que se reproduz: "[...]Esperamos que a partir deste evento os meios de comunicação compreendam que não mais é possível continuar distorcendo uma realidade - a existência de uma História, de uma Cultura Negra no Mundo e particularmente em nosso país."47

$\mathrm{Na}$ cobertura final do evento, o jornal publicaria ainda duas matérias. A primeira, relatando o debate entre dois críticos literários estrangeiros, Manuel Zapata (Colômbia) e Maximilien Laroche (Haiti, radicado no Canadá, como professor na Universidade do Quebec), em que ambos, participantes da Mostra, tecem considerações comparativas sobre a realidade brasileira, a de seus países e da diáspora africana nas Américas ${ }^{48}$. A segunda, avaliava os resultados dos debates da semana, na opinião de Maria Aparecida Santilli e Octavio Ianni ${ }^{49}$. Ambos julgaram ser a experiência extremamente valorosa, apesar de eventuais problemas de organização, ausência de escritores ou os debates terem, por vezes, fugido do tema. Seria mais importante a adesão do público e a experiência democrática do debate sendo exercitada, após muitos anos de interdição.

É importante registrar a maneira como o Perfil da Literatura Negra foi noticiado pelo Jornal do Conselho da Comunidade Negra de São Paulo. Este periódico enfatizou a presença dos escritores negros nacionais com algum protagonismo, o que pode ser

46 Idem, Ibidem.

$47 \mathrm{O}$ perfil da literatura negra. O Estado de São Paulo, Dos Leitores, 24 de maio de 1985, p. 02. Carta de Alberto Melo. 19

48 Literatura Negra, tema de reflexão. O Estado de São Paulo, 25 de maio de 1985, p. de 1985 , p. 16

49 Literatura negra, perfil deixa um saldo positivo. O Estado de São Paulo, 28 de maio 
depreendido pela missão a que se propunha, dando menos destaque que as outras matérias aos escritores estrangeiros ou pesquisadores da história social e literária do negro no Brasil. Figuram, nesse lugar, os nomes de Abdias Nascimento, Thereza Santos, Oliveira Silveira, Oswaldo de Camargo, Domício Proença Filho e Éle Semog como exemplos de intelectuais negros refletindo sobre o seu labor artístico e as questões do seu grupo social:

O papel da Literatura tem sua especificidade no processo histórico. Ela realiza aquele diálogo mais íntimo junto ao ouvido, olhos e espírito do leitor ou público. Por ser arte de palavras tem um jeito peculiar de dialogar e propor visão de mundo, espalhando um humus muito especial que pode contribuir muito como fertilizante da recodificação. E ela tem sido uma das principais expressões do movimento negro, não só na atualidade mas também na sua história antiga. Este foi um trecho do trabalho apresentado pelo poeta e escritor gaúcho Oliveira Silveira, intitulado "A Recodificação do Mundo pelo Negro na Diáspora Através da Literatura", apresentado dentro do Perfil da Literatura Negra, Mostra Internacional de São Paulo que aconteceu de 20 a 26 de maio, no Centro Cultural São Paulo. [...]A exemplo do texto citado acima e muitos outros de excelente qualidade, o evento foi sem dúvida alguma o mais importante acontecimento cultural, ligado à literatura, dos últimos 20 anos. Patrocinado pela Secretaria Municipal de Cultura, tendo a frente desses trabalhos a teatróloga Thereza Santos, que com uma equipe de profissionais competentíssimos, conseguiu um fato quase que inédito: lotar as salas do Centro Cultural por uma semana inteira, atraindo as atenções do público da Capital e do Interior, interessados em saber dos caminhos percorridos por escritores negros e brancos, através de seus trabalhos com relação à recodificação do mundo pelas palavras. Participaram especialistas renomados tanto do território nacional e internacional como Abdias do Nascimento, Gianfrancesco Guarnieri (Secretário de Cultura do Município), Domício Proença, Ele Semog, Oswaldo de Camargo, Dom Lee e Michael Mitchel, dos 
Estados Unidos, Maximiliem Larosche, do Haiti, entre outros. Não resta a menor dúvida que um grande passo foi dado, façamos votos que eventos dessa natureza não sejam atrações de 10 em 10 anos, mas que possam ocorrer pelo menos a cada dois anos, a fim de que o exercício da troca de experiências em todos os setores das atividades literárias contribuam para o enriquecimento e fortalecimento da atitude crítica perante a vida e o mundo. ${ }^{50}$

A esperança do texto sobre a Mostra não prosperou. O evento não se repetiu, nem com a mesma amplitude ou participação, a não ser no ano seguinte, durante a programação da III Bienal Nestlé de Literatura. É possível rastrear o anúncio de um II Perfil da Literatura Negra em 1987, através de duas matérias publicadas no jornal $O$ Estado de São Paulo, mas que não evidenciam o mesmo vigor de cobertura da programação demonstrado para a primeira edição do evento:

Começa amanhã e vai até o dia 22, no Centro Cultural São Paulo[...] o II Perfil da Literatura Negra - Mostra Internacional, que reunirá escritores brasileiros de mais de 15 países, todos negros para discutir a problemática do negro na arte e na cultura. O escritor Oswaldo de Camargo lançará durante o encontro o livro $O$ Negro Escrito, que faz um apanhado da participação do negro na literatura desde 1650 . O encontro é patrocinado pelo governo do estado de São Paulo, por intermédio da Secretaria de Estado da Cultura. ${ }^{51}$

Octávio Ianni, Diva Damato, Fernando A. Mourão, Paulo Colina (Brasil), David Brookshaw (Inglaterra), Manuel Zapata Olivella (Colômbia), Mazizi Kunene (África do Sul), Buschi Emecheta (Nigéria) e Rui Duarte (Angola)

50 Mostra Internacional de Literatura. Jornal do Conselho da Comunidade Negra, São Paulo, ano I, n. 03, ago/set. 1985, p. 08. de 1987 , p. 05

51 Negros discutem a sua cultura. O Estado de São Paulo, Caderno 2, 15 de novembro 
são alguns dos nomes que estão hoje debatendo "A literatura como forma de resistência" dentro do programa do II Perfil da Literatura Negra. Os debates começam às 10h, na Sala Adoniran Barbosa, no Centro Cultural São Paulo[... $]^{52}$

Sem saber qual foi a programação completa do II Perfil ${ }^{53}$, é difícil evidenciar cabalmente a secundarização, nas matérias d'O Estado de São Paulo, a presença dos escritores negros brasileiros nele. Por outro lado, pode-se afirmar que o destaque dado à presença estrangeira é visível, especialmente na segunda nota. Na primeira, o anúncio do livro de Oswaldo de Camargo pode ser entendido também como um dado interno, uma vez que o escritor era revisor e jornalista do Grupo Estado desde meados dos anos 1950 (Oswaldo atuava, à ocasião, na redação do Jornal da Tarde). Curioso que esta nota é intitulada como "Negros discutem a sua cultura". O que antes, em 1985, era algo amplo e que foi louvado por ter tido como uma ampla adesão pública, a um ano dos debates sobre o Centenário da Abolição é caracterizado como algo endógeno, como se a literatura negra e sua história devessem interessar, tão somente, aos negros e seus defensores. Nada mais é noticiado sobre a segunda edição do Perfil, apesar ser suscitado ter ocorrido ao longo de cinco dias úteis.

E aquilo que foi uma semana de debates em 1985 converteuse, em 1986, em um dia específico, durante a III Bienal Nestlé de Literatura, ocorrida no Centro de Convenções Rebouças na capital paulista. A Bienal, dedicada a revelar e premiar novos talentos literários, além de promover debates, entre os dias 07 e 11 de julho de 1986, abrigou o Seminário de Literatura Brasileira. As seções dedicadas a "O Negro na Literatura Brasileira" ocorreram ao longo do dia 09 de julho. Na parte da manhã, o expositor foi o jornalista e

52 Literatura Negra. O Estado de São Paulo, Caderno 2, 21 de novembro de 1987, p. 6.

53 Thereza Santos menciona muito rapidamente o segundo evento em sua memórias: "Foram 14 projetos dentro do "Consciência e Liberdade", de novembro de 1987 a novembro de 1988. Começamos com o "II Perfil da Literatura Negra - Mostra Internacional de São Paulo", com a maioria dos participantes da primeira edição e outros escritores e intelectuais nacionais e internacionais, como os brasilianistas Michael Michel e Ângela Guillian". SANTOS, Thereza. $O p$. Cit. p. 101. 
crítico de literatura Leo Gilson Ribeiro. O coordenador da mesa foi Duílio Gomes e os debatedores eram o escritor negro Abelardo Rodrigues e os cientistas sociais Clóvis Moura, Joel Rufino dos Santos e Octávio Ianni. Na seção da tarde, criou-se o espaço para os "Depoentes", para o qual foram convidados os escritores Adão Ventura, Audálio Dantas, Éle Semog, Oliveira Silveira, Oswaldo de Camargo, Paulo Colina e Ruth Guimarães. ${ }^{54}$ Necessário dizer que Dantas nunca se afirmou como um escritor negro mas como o descobridor de Carolina Maria de Jesus (1914-1977) e organizador das notas que se tornariam o Quarto de Despejo: diário de uma favelada(1960). Ruth Guimarães (1920-1914) foi uma escritora negra que jamais defendeu a estética negra como uma ética criativa denominada Literatura Negra, o que não significou descaso, de sua parte, com a pesquisa sobre temas e defesa das questões negras. Os outros escritores, na seção de Depoentes, todos eram ativistas da Literatura Negra Brasileira. A reunião desses nomes provocou discussões, pelo menos na primeira seção, como se pode observar do relato abaixo:

Existe racismo na literatura brasileira e todo o monopólio cultural está nas mãos dos brancos[...] $\mathrm{O}$ autor do raciocínio é o escritor, ensaísta e sociólogo Clóvis Moura que participou ontem de manhã, do terceiro debate $(\mathrm{O}$ Negro na Literatura Brasileira)[...] Na plateia alguns dos mais ativos escritores negros do país, como Arnaldo Xavier, Paulo Colina, Adão Ventura e Oswaldo de Camargo, observavam o debate que, para eles, não interfere na má vontade em analisar a literatura que produzem. "No todo, não achei o debate bom. Os debatedores brancos sempre tentam atuar como conselheiros culturais para a gente e, por maior solidariedade que exista com a nossa causa, sempre 
existe um filtro étnico racista", disse Arnaldo
Xavier.[... $]^{55}$

No tocante a Bienal Nestlé, a matéria publicada no Jornal do Conselho da Comunidade Negra de São Paulo traz sutilmente as divergências sobre um ponto já apresentado neste artigo e discutido pelos escritores negros no livro Criação Crioula, Nu Elefante Branco: o desencontro programático de autores e críticos em torno daquela ideia, permanentemente em debate ${ }^{56}$. O excerto da matéria é longo, mas sua reprodução é válida:

A importância e o caráter específico da literatura negra fizeram-na merecer um dia de debates e estudos na $3^{\text {a }}$ Bienal Nestlé de Literatura Brasileira, realizada em julho, no Centro de Convenções Rebouças, com a participação de alguns dos mais importantes escritores brasileiros do momento.[...]Os trabalhos começaram pela manhã, com uma mesa composta por Leo Gilson Ribeiro, Clóvis Moura, Abelardo Rodrigues e Otávio Ianni (sic). Ribeiro, crítico literário do Jornal da Tarde, falou da tentativa de branqueamento da sociedade brasileira iniciada no começo do século, o que levou a um abafamento da cultura negra, com reflexos na literatura brasileira. Nessa mesma linha de raciocínio, o escritor, poeta e sociólogo Clóvis Moura declarou que o negro nunca é visto como herói, na literatura oficial. E o professor e escritor Otávio Ianni ressaltou que o escritor negro precisa resgatar a verdadeira história brasileira, apresentada até agora, sempre do ponto de vista da cultura da classe dominante. [...]À tarde, o numeroso e interessado público voltou a lotar o auditório do Centro de Convenções Rebouças, para ouvir os depoimentos de escritores negros. Sentaram-se à mesa Audálio Dantas, Adão Ventura, Ele

55 SOARES, Ricardo. Páginas negras da literatura. O Estado de São Paulo, Caderno 2, 10 de julho de 1986, p. 7.

56 Literatura Negra na 3 a Bienal Nestlé.” Jornal do Conselho da Comunidade Negra, São Paulo, ano II, n.6, junho/julho 1986, p, 12. 
Semog, Oswaldo de Camargo, Oliveira Silveira, Paulo Colina e Ruth Guimarães. À exceção de Dantas, que falou sobre a escritora negra Carolina Maria de Jesus, autora de Quarto de Despejo, descoberta por ele há vinte anos na favela do Canindé (sic), em São Paulo, os escritores falaram de suas obras e de suas experiências literárias. Poetas de produção independente, e que se envolvem em todos os momentos da feitura do livro, desde a impressão até a divulgação, eis a característica comum a esses escritores. Paulo Colina, poeta e tradutor, organizador da antologia AXÉ, de poetas negros, disse que gostaria de ver mais prosadores negros. Entretanto, ele mesmo, a princípio um ficcionista, aderiu à poesia por sentir que há coisas que só se pode dizer através dela. [...]Para Oliveira Silveira, poeta gaúcho, com sete livros publicados, a literatura negra é a que está comprometida com a veiculação de dados culturais referentes ao negro. Já Paulo Colina prefere falar de uma literatura afrobrasileira, que diga o que somos e o que não queremos ser. Oswaldo de Camargo, paulista de Bragança, poeta e jornalista, um dos decanos dos escritores negros atuais, é de opinião que a literatura negra é uma tentativa de prosseguirmos sendo nós mesmos. Ruth Guimarães, que ressaltou ser professora, estabeleceu a diferença entre a literatura do negro, onde o mesmo é sujeito, e a literatura sobre o negro, onde é objeto das ações. Para o carioca Ele Semog, a literatura negra é a que apresenta a oralidade, a ginga e a resistência próprias do negro. É a que visa ao aperfeiçoamento da cultura negra, independente de quem a faz.[...]As intervenções mais marcantes da tarde foram as de Ruth Guimarães e Ele Semog. Ruth, que se definiu mulher, negra e caipira, deu depoimento altamente otimista, embora marcado pelo realismo. Depois de dizer que a máquina de escrever é a sua arma, afirmou que é totalmente livre, e que conquistou cada centímetro de seu espaço. Disse ainda que seus personagens negros são feitos de pedra e de aço, e que por meio de sua literatura ou mesmo falando a platéias como aquela, pregava sempre o orgulho: Nós estamos aqui. Queiram ou não. Só falta sermos o povo brasileiro. Para Ruth, lugar de negro é em todos os lugares, principalmente a escola. E indagou: sem escola, 
sem orgulho e sem um livro nas mãos, o que nos resta? Ele Semog lembrou que os coletivos de escritores negros ainda não estão reunindo como devia, e que ainda há muito que lutar contra os capitães de mato da criação. Ressalvou, porém, que o livro acima de ser um instrumento ideológico, deve ser uma obra de arte. E que o grupo a que pertence, no Rio de Janeiro, o NEGRICIA, pretende estabelecer, acima de tudo, uma estética desgarrada do eurocentrismo.[...] Apesar da reclamada ausência de outras escritoras negras e de pelo menos um representante do grupo Quilombhoje, uma das mais importantes experiências no gênero, no Brasil, o dia de debates sobre literatura negra, dentro da $3{ }^{\text {a }}$ Bienal Nestlé de Literatura Brasileira, foi dos mais produtivos. Esperase que outras iniciativas nesse sentido sejam tomadas, bem como que haja continuidade deste trabalho.

Em ambos os eventos, as ausências dos escritores do Quilombhoje, como coletivo [Cuti, Abílio Ferreira, Esmeralda Ribeiro, Oubi Inaê Kibuko, Míriam Alves, Esmeralda Ribeiro, Márcio Barbosa e Sônia Conceição] foi perceptível. Pode-se argumentar que, pelo tamanho do grupo, seria difícil inseri-los como um todo. Mas ao menos um ou dois membros seriam possíveis. Tratase do terreno de disputas de legitimidade discursiva sobre os sentidos da literatura negra, estabelecido nos anos 1980, entre escritores (mais velhos e jovens ativistas), críticos literários e membros da política cultural. Pouco mais de vinte anos após os fatos, os atuais coordenadores do Quilombhoje [Barbosa e Ribeiro ${ }^{57}$ ] rememoram

57 Esmeralda Ribeiro: "[...]o "Perfil" foi a Tereza, né? Tereza Santos. Ela só fez porque tinha uma produção, tinha autores pra mostrar. Eu acho que foi muito rico. Pra nós foi riquíssimo. Um período muito bom, no sentido da divulgação, da discussão, de trazer também mais acadêmicos, críticos, a academia, na verdade.” Márcio Barbosa: “[...]Eu acho que foi uma coisa de você colocar caminhos, eu tinha uma concepção, a Esmeralda tinha outra, o Oswaldo tinha outra, o Cuti tinha outra, e foram mil ideias que fervilhavam. Foi legal, porque a gente começou a ditar algumas coisas aí. E o "Perfil", cara, eu acho que surgiu um pouco dessas discussões todas, dessa agitação toda. Por outro lado, a gente não foi convidado pro "Perfill", pra participar como palestrante, pra estar falando na mesa. A gente ficou um pouco, o Quilombhoje ficou meio que à parte desse processo. Tanto que a gente ficou até admirado, né? Pô, um Perfil internacional... Teve escritores angolanos, moçambicanos e tal. E foi bacana, a gente participou lá, estivemos todos os 
aqueles eventos com saldo muito positivo, mesmo com os desencontros, disputas e percalços. O debate e a visibilidade sobre a literatura, os intelectuais e o grupo social negros estava acima disso tudo.

\section{Conclusão}

Pelo que tentou demostrar ao longo do artigo, houve uma ambiência intelectual e política extremamente favorável ao debate e circulação de ideias sobre o grupo social negro e acerca de sua literatura. Isso congregou intelectuais, negros e não-negros, que por vezes estabeleceram alianças políticas e culturais, seja para organização de eventos, publicação de livros ou debates públicos. Num cenário de progressiva abertura política, tais fatos, obras e ideias colocam em evidência a vitalidade do associativismo político e intelectual negro, bem como a importância da questão racial no Brasil, em meio à última ditadura civil-militar (1964-1985).

Caso isso não seja levado em consideração, fica difícil explicar como os sujeitos sociais, os eventos narrados e as publicações citadas foram possíveis, apesar de frequentemente ignorados pela historiografia que se ocupa do período ditatorial, da produção da literatura marginal dos anos 1970 ou mesmo do debate sobre a questão racial. O ano de 1978 é considerado um marco do ressurgimento do movimento negro no Brasil - por assumir a ressignificação simbólica do 20 de novembro como data de luta do grupo negro, pela fundação do Movimento Negro Unificado ou pela criação de coletivos como os Cadernos Negros. Todavia, as ideias possuem força social e devem ser rastreadas em seus percursos. As décadas pregressas não foram estéreis ou desertificadas, mesmo apesar do golpe de 1964, que desmobilizou associações como a Associação Cultural do Negro. E tal força social das ideias também

dias...” Entrevistas com Esmeralda Ribeiro e Márcio Barbosa, concedidas a Mário Augusto M. Da Silva e Vinebaldo Aleixo de Souza Filho, em 26/02/2010. 
devem ser debatidas enquanto consequências. A confluência de militantes velhos e novos, as circunstâncias em torno de 1978 podem ser explicativas para o desenrolar da década de 1980. Desta maneira, por mais extraordinário que possa se aparentar, o período em tela não é exatamente excepcional, mas sim a resultante de uma longa discussão e atuação de diferentes sujeitos na história do associativismo político cultural negro, especialmente em São Paulo.

Outro destaque é a importância do Perfil da Literatura Negra e dos debates na III Bienal Nestlé. Mesmo com os problemas apontados, não se pode ignorar a importância de se reunir os intelectuais e escritores enfocados, para discutir, num primeiro plano, a perspectiva diaspórica da presença africana e negra em outros continentes, extraindo daí um saldo em termos de literatura e política. De outro ângulo, a possibilidade de se debater a história social e literária negra e também ouvir seus intelectuais deve ser interpretado como algo de valor. Tratava-se de uma conjuntura de recém saída de mais um período de abuso de poder institucional.

Dada a história brasileira, assumir e/ou colocar em discussão a existência de racismo, preconceito, discriminação racial; ou mesmo respeitar a fala do negro como intelectual não faz parte de um repertório convencional. Esse debate é tão somente suscitado neste artigo. Pesquisas mais profundas sobre esse momento e aqueles eventos necessitam ser mais e melhor elaboradas, especialmente se valendo do uso de fontes e metodologia de História Oral, uma vez que os documentos ou jornais à disposição são escassos e os eventos aniversariam já algo em torno de três décadas de acontecimento, com o falecimento de alguns de seus protagonistas (Adão Ventura, Thereza Santos, Arnaldo Xavier, Jônatas Conceição, Paulo Colina, Oliveira Silveira, Ruth Guimarães, Octávio Ianni, Gianfrancesco Guarnieri, Leo Gilson Ribeiro entre outros).

RECEBIDO EM: 02/01/2016 APROVADO EM: 19/04/2016 